\title{
AN IMPROVED WHITE CELL DILUENT FOR USE WITH THE EEL ELECTRONIC BLOOD CELL COUNTER
}

\author{
BY \\ F. TAYLOR AND A. G. RICKARDS \\ From the Royal Infirmary, Lancaster
}

(RECEIVED FOR PUBLICATION DECEMBER 12, 1959)

\begin{abstract}
An improved white cell diluent for use with the Eel electronic counter is described. It possesses advantages over previously described diluents in the rapidity of its action as a red cell stromalysin and in its ability to conserve surviving leucocytes for long periods of time. These properties enable counts to be made either immediately after preparation of the suspension or several hours later. The diluent is equally suitable for use with capillary or venous blood samples. When used for counting leucocytes it has been found necessary to effect a minor modification to the machine whereby the light intensity is reduced by approximately one-half.
\end{abstract}

The advantages of using electronic aids in the counting of red cells have been clearly established for some time, but as yet the counting of white cells has proved much less satisfactory because of difficulty in finding a suitable diluent. After several months' trial with previously recommended diluents for the Eel and other electronic counters it became clear that none of them was ideal for routine use with the Eel counter, and accordingly an investigation was undertaken with the object of developing a white cell diluent which would conform to the following requirements: (a) It should be equally adaptable for both visual and electronic counting of leucocytes. (b) It should be capable of lysing red cells quickly so that counts could be made immediately after the suspension has been prepared. (c) The cell suspension should remain stable for at least 12 hours so that counts could be made several hours after preparation. . (d) It should be equally adaptable for both capillary and venous blood samples.

After experimenting with a large number of different lysing agents we believe we have found a diluent which fulfils these criteria. It has also been our experience that the efficiency of the Eel machine in counting leucocytes is much improved by making a minor modification to the dark-field illumination.

\section{Preparation of Suspension}

The following stock solution of diluent is prepared freshly each week:

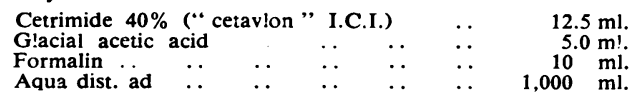

From this stock solution a volume sufficient for one day's use is filtered through sintered glass into a scrupulously clean glass container stoppered with rubber or glass. The importance of avoiding metal stoppers is emphasized, as it has been found that the diluent exerts a chemical action upon aluminium, causing the release of particles which may seriously affect the accuracy of the count. It is also important to avoid contamination by dust or other particles which may either interfere with the efficiency of the jets or register as leucocytes.

Cetrimide in acid solution has been found to be a very effective stromalysin, and leucocytes may be counted within seconds of mixing with the diluent, and remain unaffected for at least 24 hours at room temperature. If the mixture is stored at $4^{\circ} \mathrm{C}$. accurate visual and electronic counts may be made after the lapse of several days. The solution is equally suitable for use with venous blood treated with "sequestrene" (E.D.T.A.) or capillary blood pipetted directly into the diluent. Oxalated blood is not suitable for use in the electronic counting of leucocytes. In common with other detergents cetrimide tends to froth when shaken vigorously; in practice this property has been found not to impair the accuracy of the counts in any way.

Various strengths of cell suspension have been used in this investigation, and it has been found that a dilution of 1 in 20 is the most satisfactory for routine use. Venous or capillary blood, $0.05 \mathrm{ml}$., is pipetted into $0.95 \mathrm{ml}$. diluent and transferred to a small-bore sampling tube of approximately $\frac{3}{8}$ in. diameter. In order to avoid the introduction of cell debris from the skin of the finger the tubes are sealed with a clean rubber stopper before mixing. Counts may be made after the lapse of a few seconds or left overnight at room temperature and counted on the following morning. 


\section{Modification to Counter}

For the accurate counting of white cells the sensitivity of the machine must be reduced to a point where small aggregates, such as red cell debris, are not registered on the dark-ground field. Small particles of this size are normally included in the counting of red cells, but their number in relation to the total count is so small that their inclusion does not lead to any significant error. In the counting of a much smaller number of leucocytes this error cannot be permitted, and it is accordingly necessary to reduce the sensitivity of the machine by the simple device of reducing the intensity of the light source. This may be most easily accomplished by inserting a suitable resistance (approximately $\frac{1}{4} \mathrm{ohm}$ ) in the light circuit, or more simply by impeding the light path by the introduction of a neutral grey screen or iris diaphragm. It has been our experience that a reduction of approximately $50 \%$ in the light intensity permits the accurate counting of white cells over a

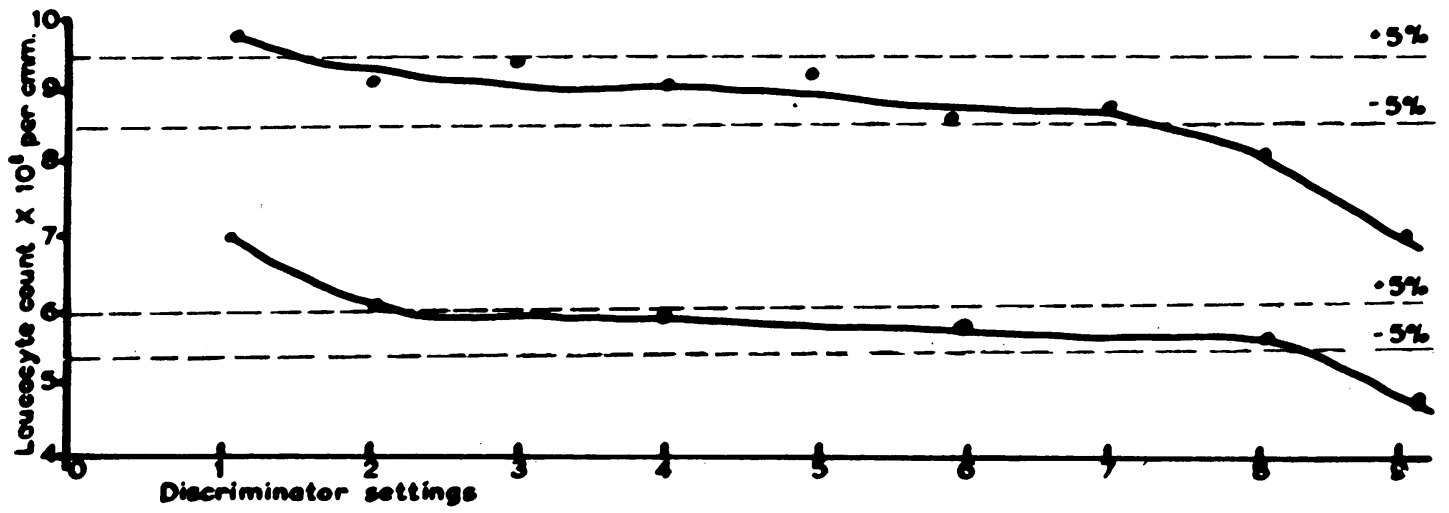

FIG. 1.-Typical plateaux of leucocyte counts (dilution 1 in 20).

TABLE

RELATIONSHIP BETWEEN 30 VISUAL AND ELECTRONIC LEUCOCYTE COUNTS AT VARYING DILUTIONS

\begin{tabular}{|c|c|c|c|c|c|c|c|c|}
\hline \multicolumn{3}{|c|}{ Visual Count } & \multicolumn{6}{|c|}{ Machine Count } \\
\hline \multirow{2}{*}{ Dilution } & \multirow{2}{*}{$\begin{array}{c}\text { Cells } \\
\text { Counted }\end{array}$} & \multirow{2}{*}{$1 \underset{\times 10^{3}}{\begin{array}{c}\text { Total } \\
\text { Count }\end{array}}$} & \multirow{2}{*}{$\begin{array}{c}\text { Mean of } \\
5 \text { Counts } \\
\times 10^{3}\end{array}$} & \multicolumn{5}{|c|}{ Cells Counted } \\
\hline & & & & 1st & 2nd & $3 \mathrm{rd}$ & $4: h$ & Sth \\
\hline 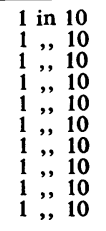 & $\begin{array}{l}395 \\
398 \\
244 \\
487 \\
329 \\
315 \\
244 \\
441 \\
445 \\
514\end{array}$ & $\begin{array}{r}9.87 \\
9.95 \\
6.10 \\
12 \cdot 17 \\
8.22 \\
7.87 \\
6.10 \\
11.02 \\
11.12 \\
12.85\end{array}$ & \begin{tabular}{r|}
9.92 \\
9.31 \\
5.97 \\
12.69 \\
7.99 \\
7.61 \\
6.26 \\
11.51 \\
11.62 \\
13.19
\end{tabular} & $\begin{array}{l}2,941 \\
2,848 \\
1,779 \\
3,854 \\
2,457 \\
2,313 \\
1,808 \\
3,559 \\
3,625 \\
3,905\end{array}$ & $\begin{array}{l}3,012 \\
2,751 \\
1,742 \\
3,786 \\
2,359 \\
2,347 \\
1,899 \\
3,467 \\
3,419 \\
4,061\end{array}$ & $\begin{array}{l}3,057 \\
2,848 \\
1,829 \\
3,838 \\
2,400 \\
2,240 \\
1,962 \\
3,347 \\
3,611 \\
3,886\end{array}$ & $\begin{array}{l}2,956 \\
2,753 \\
1,797 \\
3,756 \\
2,424 \\
2,252 \\
1,912 \\
3,448 \\
3,324 \\
3,952\end{array}$ & $\begin{array}{l}2,927 \\
2,770 \\
1,820 \\
3,809 \\
2,353 \\
2,274 \\
1,809 \\
3,445 \\
3,458 \\
3,982\end{array}$ \\
\hline 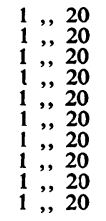 & $\begin{array}{l}308 \\
340 \\
495 \\
274 \\
469 \\
275 \\
796 \\
464 \\
350 \\
419\end{array}$ & $\begin{array}{r}6 \cdot 84 \\
7.55 \\
11.00 \\
6.09 \\
10 \cdot 42 \\
6 \cdot 11 \\
17.68 \\
10 \cdot 31 \\
7.77 \\
9 \cdot 31\end{array}$ & $\begin{array}{r}7 \cdot 07 \\
7 \cdot 61 \\
10 \cdot 95 \\
5 \cdot 58 \\
10 \cdot 82 \\
6 \cdot 59 \\
17 \cdot 32 \\
10 \cdot 78 \\
7.81 \\
9.94\end{array}$ & $\begin{array}{l}1,067 \\
1,132 \\
1,646 \\
851 \\
1,604 \\
1,017 \\
2,455 \\
1,606 \\
1,146 \\
1,484\end{array}$ & $\begin{array}{l}1,025 \\
1,151 \\
1,708 \\
874 \\
1,572 \\
986 \\
2,692 \\
1,646 \\
1,195 \\
1,521\end{array}$ & $\begin{array}{r}1,058 \\
1,089 \\
1,641 \\
847 \\
1,646 \\
993 \\
2,600 \\
1,610 \\
1,187 \\
1,519\end{array}$ & $\begin{array}{l}1,091 \\
1,167 \\
1,607 \\
779 \\
1,657 \\
2968 \\
2,600 \\
1,633 \\
1,187 \\
1,444\end{array}$ & $\begin{array}{r}1,067 \\
1,171 \\
1,615 \\
837 \\
1,641 \\
979 \\
2,643 \\
1,603 \\
1,143 \\
1,460\end{array}$ \\
\hline 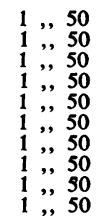 & $\begin{array}{l}727 \\
352 \\
385 \\
841 \\
640 \\
943 \\
386 \\
475 \\
492 \\
706\end{array}$ & $\begin{array}{r}11.36 \\
5.50 \\
6.01 \\
13.14 \\
10.00 \\
14.73 \\
6.03 \\
7.42 \\
7.68 \\
11.03\end{array}$ & $\begin{array}{r}11 \cdot 61 \\
5.84 \\
6 \cdot 74 \\
12.03 \\
10.09 \\
15.27 \\
5.81 \\
7 \cdot 56 \\
7.83 \\
10.89\end{array}$ & $\begin{array}{l}661 \\
368 \\
400 \\
751 \\
606 \\
895 \\
371 \\
429 \\
457 \\
631\end{array}$ & $\begin{array}{l}690 \\
366 \\
442 \\
751 \\
601 \\
872 \\
315 \\
439 \\
431 \\
665\end{array}$ & $\begin{array}{l}702 \\
330 \\
360 \\
640 \\
617 \\
924 \\
343 \\
451 \\
472 \\
699\end{array}$ & $\begin{array}{l}728 \\
347 \\
427 \\
713 \\
569 \\
906 \\
388 \\
454 \\
498 \\
607\end{array}$ & $\begin{array}{l}703 \\
342 \\
394 \\
755 \\
634 \\
985 \\
326 \\
497 \\
493 \\
665\end{array}$ \\
\hline
\end{tabular}


range of discriminator settings comparable to that normally achieved in counting red cells on the unmodified machine (Fig. 1).

\section{Comparison with Visual Counts}

The accuracy of the mechanical counter has been verified by comparison with 264 visual counts which formed a sequential series of routine white cell counts performed in the haematology department. In all cases the visual counts were done before the electronic, and both counts were carried out on the same cell suspension. Each machine count was computed as the mean of three readings. In 209 cases a cell suspension diluted 1 in 50 was used, and in 55 cases a 1 in 20 dilution was employed. This investigation showed that $62.9 \%$ of the electronic counts fell within \pm 1 standard deviation of the visual counts, $92 \%$ fell within \pm 2 s.d., and $99.2 \%$ fell within \pm 3 s.d.

A second investigation was then carried out with the purpose of reducing the inherent error in both the visual and electronic methods by counting a larger number of cells than is usual in the routine technique. Thirty samples of blood were visually counted for their leucocyte content, the cases being divided into three groups of 10 samples, diluted 1 in 10,1 in 20 , and 1 in 50 . The total number of cells visually counted in each case varied from 274 to 943 . From the same suspensions electronic counts were then made. Each count was repeated five times, and the mean of each count was computed from three samplings so that each suspension was fed into the machine 15 times. The results of this investigation are shown in the Table, where it will be seen that very close correlation between the visual and electronic counts was achieved.

\section{Discussion}

Several diluents for the electronic counting of white cells have been described, but all seem to possess disadvantages of one sort or another.
Boxall (1959) suggested the use of the non-ionic detergent " nonidet" P.40, but not only does this solution become turbid, due to precipitated surfactant, on slight rises of temperature, but the suspension is unstable, necessitating counting the white cells within half an hour of preparing the suspension. Richar and Breakell (1959), working with the Coulter counter, recommended saponin as a lysing agent. This diluent also possesses serious disadvantages, for not only must counts be completed within one hour of preparation but occasional agitation must be carried out for 10 to 15 minutes before counting. We have ourselves used various saponin-containing diluents and have found them all greatly inferior to cetrimide acetic acid diluent. Akeroyd et al. (1959) have recently recommended " triton X 100 " as a lysing agent, but here also the cytolytic effect on leucocytes was found to be too rapid to allow of a reasonable interval between preparation of the cell suspension and counting the cells (Richar and Breakell, 1959).

The cetrimide acetic diluent recommended here does not appear to possess any of these disadvantages, for while stromalysis of red cells is almost immediate its cytolytic effect on white cells is not apparent for at least 24 hours when kept at room temperature.

A recently developed wetting agent, " hyamine 2389," prepared by the Rohm and Haas Co. for use with chemical auto analysers, has been tested for its suitability as a white cell diluent, and preliminary investigations suggest that it possesses many of the advantages of cetrimide.

\section{REFERENCES}

Akeroyd et al. (1959). Cited by Richar and Breakell (1959). Boxall, S. J. (1959). Gaz. Inst. Med. Lab. Tech., 5, 49. Richar, W. J., and Breakell, E. S. (1959). Amer. J. clin. Path., $31,384$. 